\title{
PERAMALAN HARGA EMAS MENGGUNAKAN METODE AVERAGE BASED AND FUZZY LOGIC RELATIONSHIP
}

\author{
A. M. P. Pratiwi 1 , S. Musdalifah ${ }^{2}$, dan D. Lusiyanti ${ }^{3}$ \\ 1,2,3 Program Studi Matematika Jurusan Matematika FMIPA Universitas Tadulako \\ Jalan Soekarno-Hatta Km. 09 Tondo, Palu 94118, Indonesia. \\ 1afrillyaputry@gmail.com, 2selvymusdalifah@gmail.com, 33desylusiyanti@untad.ac.id
}

\begin{abstract}
Gold is an alternative that most people tend to choose to invest for several reasons, one of which is profitable. To obtain optimal returns, investors must know the movement of gold prices so that the investors know when to buy gold and when to sell gold. Gold price movements can be monitored by forecasting. The forecasting method used in this research is average based and fuzzy logic relationship which is a method with the concept of fuzzy logic. This method provides a level of accuracy calculated using MAPE (Mean Absolute Percentage Error) of 0,0496\%. The results showed that forecasting gold price movements in October 2020 - December 2021 in the price range of $R p 876.975 / \mathrm{gram}$ - Rp909.725/gram with the highest gold price occurred in December 2020.
\end{abstract}

Keywords : : Average Based, Fuzzy Logic Relationship, Gold Price, MAPE, Forecasting.

\section{ABSTRAK}

Emas merupakan alternatif yang cenderung dipilih kebanyakan orang untuk berinvestasi karena beberapa alasan, salah satunya menguntungkan. Untuk memperoleh keuntungan yang optimal, pelaku investasi harus mengetahui pergerakan harga emas sehingga pelaku investasi tahu kapan harus membeli emas dan kapan harus menjual emas. Pergerakan harga emas dapat dipantau dengan peramalan. Metode peramalan yang digunakan dalam penelitian ini adalah average based and fuzzy logic relationship yang merupakan salah satu metode dengan konsep fuzzy logic. Metode tersebut memberikan tingkat akurasi yang dihitung menggunakan MAPE (Mean Absolute Percentage Error) sebesar 0,0496\%. Hasil penelitian menunjukkan bahwa peramalan pergerakan harga emas pada bulan Oktober 2020 - Desember 2021 dalam rentang harga Rp 876.975/gram - Rp 906.725/gram dengan harga emas tertinggi terjadi pada bulan Desember 2020.

Kata Kunci $\quad$ : Average Based, Fuzzy Logic Relationship, Harga Emas, MAPE, Peramalan. 


\section{PENDAHULUAN}

Pola pikir masyarakat yang semakin maju menimbulkan keinginan untuk terus mengelola pendapatannya agar tetap terjaga guna keperluan yang akan datang. Investasi merupakan salah satu cara yang bisa dilakukan untuk mengembangkan harta kekayaan yang dimiliki secara produktif. Sebagian besar orang melakukan investasi dilandasi oleh banyaknya ketidakpastian yang akan dihadapi di masa depan. Kebutuhan kita di masa yang akan datang sangat mungkin berubah. Bisa saja kita mendadak jatuh sakit, dunia mengalami kelangkaan bahan bakar minyak, harga barang membumbung tinggi, biaya kuliah naik drastis, dan sebagainya. Inilah mengapa perencanaan masa depan melalui investasi perlu dilakukan (Iman, 2008).

Saat ini, kita bisa menentukan banyak pilihan yang dapat digunakan untuk berinvestasi seperti emas, barang antik, properti, saham, dan lain-lain. Emas merupakan alternatif yang cenderung dipilih kebanyakan orang untuk berinvestasi karena beberapa alasan seperti alasan menguntungkan (profitable), mudah dicairkan (hight liquidity), resiko rendah (low risk), tidak memerlukan dana besar, mudah dipindahkan (portable), kepemilikan dan pengelolaan sendiri (ownership and stewardship) (Sitohang dan Siringo, 2018). Emas merupakan objek investasi yang nilainya cenderung selalu naik, sehingga investasi dalam bentuk emas dapat dikatakan hampir selalu menguntungkan dengan resiko yang relatif kecil (Fajri, 2017). Namun, bukan berarti harga emas tidak pernah turun. Oleh sebab itu, pelaku investasi harus mengetahui pergerakan harga emas sehingga pelaku investasi tahu kapan harus membeli emas dan kapan harus menjual emas agar mendapatkan keuntungan yang optimal.

Pergerakan harga emas yang akan datang dapat dipantau dengan menggunakan peramalan. Terdapat beberapa metode yang dapat digunakan untuk melakukan peramalan, salah satunya adalah fuzzy logic. Penelitian yang terkait dengan metode fuzzy logic dalam peramalan harga emas pernah dilakukan sebelumnya oleh Sitohang dan Siringo (2018) yaitu tentang analisis peramalan harga emas dengan metode automatic clustering and fuzzy logic relationship dimana automatic clustering digunakan untuk menentukan panjang interval dan metode fuzzy logic relationship untuk meramalkan harga emas dengan nilai akurasi peramalan yang diperoleh dengan menggunakan MAPE yaitu 5,3\%. Akan tetapi, menurut Rukhansah dkk (2016) salah satu metode penentuan panjang interval yang efektif adalah average based yang diusulkan oleh Xihao dan Yimin (2008).

Sehingga berdasarkan latar belakang tersebut, penulis tertarik untuk melakukan penelitian yang sama namun menggunakan metode yang berbeda dalam menentukan panjang interval yaitu menggunakan algoritma average based kemudian menggunakan metode fuzzy logic relationship untuk mendapatkan hasil peramalan harga emas berdasarkan data runtun waktu pergerakan harga emas yang diberi judul "Peramalan Harga Emas Menggunakan Metode Average Based and Fuzzy Logic Relationship". 


\section{METODE PENELITIAN}

Lokasi pengolahan data dilakukan di Laboratorium Komputer Jurusan Matematika Fakultas Matematika dan IImu Pengetahuan Alam, Universitas Tadulako. Sumber data yang digunakan merupakan data sekunder yaitu berupa data harga emas 24 karat yang diperoleh dari link resmi emas https://harga-emas.org/. Jenis data yang digunakan adalah data kuantitatif yaitu data pergerakan harga emas harian dalam kurun waktu 6 tahun 9 bulan terakhir mulai bulan Januari 2014 - September 2020.

Penelitian ini dilakukan dengan tahap menentukan panjang interval data harga emas 24 karat menggunakan average based yaitu dengan cara membagi dua nilai rata-rata selisih absolute. Selanjutnya, menentukan basis nilai untuk mendapatkan interval berbasis nilai rata-rata. Kemudian melakukan pengolahan data harga emas 24 karat dengan menggunakan metode fuzzy logic relationship orde 1 , orde 2 , orde 3 , dan orde 4 untuk memperoleh hasil peramalan harga emas bulan Oktober 2020 - Desember 2021 dalam IDR yaitu dengan cara menentukan himpunan semesta pembicaraan, mendefinisikan himpunan fuzzy, fuzzifikasi data, menentukan relasi logika fuzzy, defuzzifikasi dan memperoleh hasil peramalan. Kemudian menguji tingkat akurasi hasil peramalan harga emas 24 karat dengan menggunakan MAPE.

\section{HASIL DAN PEMBAHASAN}

\subsection{Hasil}

Dalam penelitian ini, data yang digunakan adalah data harga emas bulanan yang diambil dari rata-rata data harga emas harian pada bulan Januari 2014 - September 2020 seperti yang disajikan dalam Tabel 1.

Tabel 1 : Data harga emas 24 karat per gram dalam rupiah

\begin{tabular}{|c|c|c|c|c|c|c|c|c|}
\hline \multirow{2}{*}{ No. } & \multirow{2}{*}{ Bulan } & \multicolumn{7}{|c|}{ Tahun } \\
\cline { 3 - 9 } & & 2014 & 2015 & 2016 & 2017 & 2018 & 2019 & 2020 \\
\hline 1. & Januari & 488222 & 505493 & 488732 & 511789 & 572708 & 588836 & 688784 \\
\hline 2. & Februari & 498420 & 503124 & 523878 & 529941 & 581538 & 595777 & 706989 \\
\hline 3. & Maret & 491356 & 495424 & 526955 & 527905 & 586635 & 593899 & 779341 \\
\hline 4. & April & 477877 & 499576 & 526177 & 543109 & 592341 & 584345 & 859511 \\
\hline 5. & Mei & 477997 & 505792 & 542063 & 533705 & 589634 & 593724 & 824617 \\
\hline 6. & Juni & 489516 & 505855 & 549056 & 539513 & 576741 & 623837 & 792736 \\
\hline 7. & Juli & 491844 & 487095 & 565540 & 531047 & 574235 & 638401 & 862791 \\
\hline 8. & Agustus & 488248 & 495985 & 566062 & 550428 & 562453 & 687310 & 934132 \\
\hline 9. & September & 472994 & 521824 & 559522 & 563231 & 572044 & 684030 & 917295 \\
\hline 10. & Oktober & 477667 & 513833 & 530766 & 557419 & 593777 & 678863 & - \\
\hline 11. & November & 460725 & 476979 & 528382 & 557558 & 576966 & 665454 & - \\
\hline 12. & Desember & 480080 & 476867 & 496906 & 552728 & 583550 & 667423 & - \\
\hline
\end{tabular}




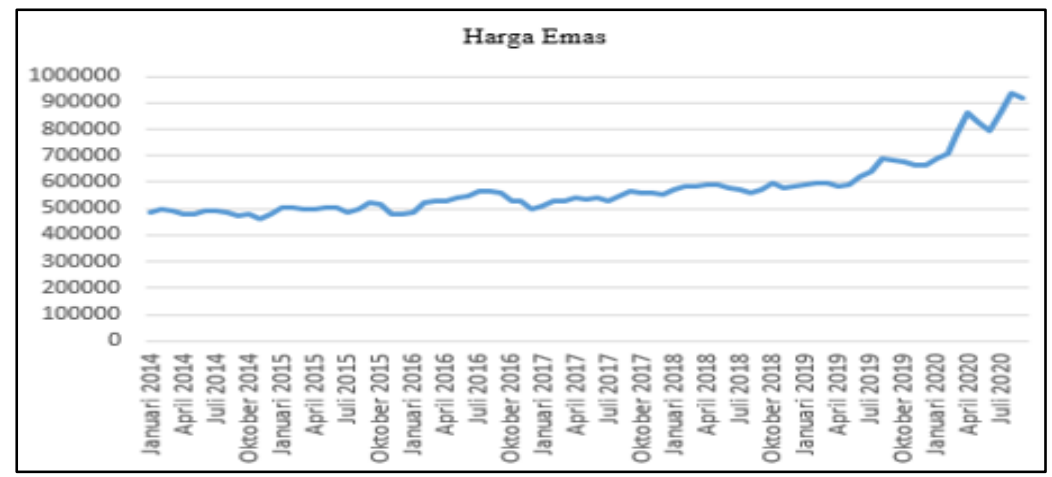

Gambar 1 : Grafik pergerakan harga emas

\subsubsection{Penerapan Algoritma Average Based}

Langkah 1. Menghitung nilai selisih absolute

Perhitungan nilai selisih absolute dapat dilakukan dengan menggunakan persamaan sebagai berikut:

$$
\text { Selisih absolute }=\left|D_{t+1}-D_{t}\right|
$$

dengan $t=1,2, \ldots, 80$ dan $D_{t}$ adalah data ke-t.

Berdasarkan persamaan (1), maka perhitungan nilai selisih absolute dapat disajikan dalam Tabel 2.

Tabel 2 : Perhitungan nilai selisih absolute

\begin{tabular}{|c|c|c|c|}
\hline No. & Periode & Data & Selisih Absolute \\
\hline 1. & Januari 2014 & 488222 & 10198 \\
\hline 2. & Februari 2014 & 498420 & 7064 \\
\hline 3. & Maret 2014 & 491356 & 13479 \\
\hline 4. & April 2014 & 477877 & 120 \\
\hline 5. & Mei 2014 & 477997 & 11519 \\
\hline$\vdots$ & $\vdots$ & $\vdots$ & $\vdots$ \\
\hline 80. & Agustus 2020 & 934132 & 16837 \\
\hline 81. & September 2020 & 917295 & - \\
\hline
\end{tabular}

Langkah 2. Menghitung rata-rata nilai selisih absolute

Untuk memperoleh rata-rata nilai selisih absolute yang disajikan dalam tabel 2 dapat digunakan persamaan sebagai berikut :

$$
\bar{D}=\frac{\sum_{t=1}^{80} D_{t}}{n}
$$

dimana $D_{t}$ adalah data ke- $t$ dan $n$ adalah banyaknya data yaitu 80 data.

Berdasarkan persamaan (2), maka diperoleh perhitungan sebagai berikut :

$$
\begin{aligned}
\bar{D} & =\frac{\sum_{t=1}^{80} D_{t}}{n} \\
& =\frac{10198+7064+13479+120+11519+\cdots+16837}{80}
\end{aligned}
$$




$$
=15218,4625
$$

Sehingga, rata-rata nilai selisih absolute yang diperoleh yaitu 15218,4625 .

Langkah 3. Menghitung $\frac{1}{2}$ rata-rata nilai selisih absolute

Perhitungan $\frac{1}{2}$ rata-rata nilai selisih absolute dapat dilakukan dengan menggunakan persamaan sebagai berikut :

$$
\frac{1}{2} \text { rata }- \text { rata }=\frac{\bar{D}}{2}
$$

Berdasarkan persamaan (3), maka diperoleh perhitungan sebagai berikut :

$$
\begin{gathered}
\frac{1}{2} \text { rata }- \text { rata }=\frac{\bar{D}}{2} \\
=\frac{15218,4625}{2} \\
=7609,2312
\end{gathered}
$$

Sehingga, $\frac{1}{2}$ rata-rata nilai selisih absolute yang diperoleh yaitu 7609,2312.

Langkah 4. Menentukan interval berbasis rata-rata.

Tabel 3 : Pemetaan basis peramalan

\begin{tabular}{|c|c|}
\hline Range & Basis \\
\hline $0,1-1,0$ & 0,1 \\
\hline $1,1-10$ & 1 \\
\hline $11-100$ & 10 \\
\hline $101-1000$ & 100 \\
\hline $1001-10000$ & 1000 \\
\hline
\end{tabular}

Nilai $\frac{1}{2}$ rata-rata selisih absolute yang diperoleh pada langkah sebelumnya yaitu 7609,2312 . Berdasarkan tabel 3, nilai tersebut terletak pada range $1001-10000$ maka basis yang diperoleh adalah 1000. Sehingga berdasarkan basis tersebut, diperoleh panjang interval adalah 1000. Panjang interval tersebut akan digunakan untuk membagi interval himpunan semesta menjadi beberapa interval.

\subsubsection{Perhitungan Metode Fuzzy Logic Relationship dalam Peramalan Harga Emas pada Data Training}

Mendefiniskan interval himpunan semesta yang memuat semua data dengan persamaan sebagai berikut :

$$
U=\left[D_{\min }, D_{\max }\right]
$$

dimana $D_{\min }$ adalah data terkecil dan $D_{\max }$ adalah data terbesar. Berdasarkan persamaan (4), maka dapat dituliskan sebagai berikut :

$$
U=[460725,934132]
$$

Interval himpunan semesta $U$ kemudian dibagi menjadi beberapa interval dengan panjang yang sama. Selanjutnya, setiap interval $\left(u_{i}\right)$ yang terbentuk dihitung nilai tengahnya $\left(m_{i}\right)$ dengan persamaan sebagai berikut :

$$
m_{i}=\frac{\text { batas atas }+ \text { batas bawah }}{2}
$$


Tabel 4 : Interval dan nilai tengah

\begin{tabular}{|c|c|c|}
\hline No. & Interval $\left(\boldsymbol{u}_{\boldsymbol{i}}\right)$ & Nilai Tengah $\left(\boldsymbol{m}_{\boldsymbol{i}}\right)$ \\
\hline 1. & $u_{1}=[460725,461725)$ & $m_{1}=461225$ \\
\hline 2. & $u_{2}=[461725,462725)$ & $m_{2}=462225$ \\
\hline 3. & $u_{3}=[462725,463725)$ & $m_{3}=463225$ \\
\hline$\vdots$ & $\vdots$ & $\vdots$ \\
\hline 473. & $u_{473}=[932725,933725)$ & $m_{473}=933225$ \\
\hline 474. & $u_{474}=[933725,934725)$ & $m_{474}=934225$ \\
\hline
\end{tabular}

\section{Langkah 1. Proses fuzzifikasi}

a. Mendefinisikan himpunan fuzzy $A_{i}$ dari himpunan $U$

$$
\begin{aligned}
& A_{1}=\left\{\frac{1}{u_{1}}+\frac{0,5}{u_{2}}+\frac{0}{u_{3}}+\frac{0}{u_{4}}+\frac{0}{u_{5}}+\frac{0}{u_{6}}+\cdots+\frac{0}{u_{473}}+\frac{0}{u_{477}}\right\} \\
& A_{2}=\left\{\frac{0,5}{u_{1}}+\frac{1}{u_{2}}+\frac{0,5}{u_{3}}+\frac{0}{u_{4}}+\frac{0}{u_{5}}+\frac{0}{u_{6}}+\cdots+\frac{0}{u_{473}}+\frac{0}{u_{474}}\right\} \\
& A_{3}=\left\{\frac{0}{u_{1}}+\frac{0,5}{u_{2}}+\frac{1}{u_{3}}+\frac{0,5}{u_{4}}+\frac{0}{u_{5}}+\frac{0}{u_{6}}+\cdots+\frac{0}{u_{473}}+\frac{0}{u_{474}}\right\} \\
& A_{474}=\left\{\frac{0}{u_{1}}+\frac{0}{u_{2}}+\frac{0}{u_{3}}+\frac{0}{u_{4}}+\frac{0}{u_{5}}+\frac{0}{u_{6}}+\cdots+\frac{0,5}{u_{473}}+\frac{1}{u_{474}}\right\}
\end{aligned}
$$

b. Fuzzifikasi setiap data numerik kedalam himpunan fuzzy $A_{i}$

Tabel 5 : Himpunan fuzzy $A_{i}$ terhadap interval $u_{i}$

\begin{tabular}{|c|c|c|}
\hline No. & Interval & Himpunan Fuzzy \\
\hline 1. & $u_{1}$ & $A_{1}$ \\
\hline 2. & $u_{2}$ & $A_{2}$ \\
\hline 3. & $u_{3}$ & $A_{3}$ \\
\hline$\vdots$ & $\vdots$ & $\vdots$ \\
\hline 473. & $u_{473}$ & $A_{473}$ \\
\hline 474. & $u_{474}$ & $A_{474}$ \\
\hline
\end{tabular}

Tabel 6 : Fuzzifikasi data

\begin{tabular}{|c|c|c|}
\hline No. & Interval & Himpunan Fuzzy \\
\hline 1. & $u_{1}$ & $A_{1}$ \\
\hline 2. & $u_{2}$ & $A_{2}$ \\
\hline 3. & $u_{3}$ & $A_{3}$ \\
\hline$\vdots$ & $\vdots$ & $\vdots$ \\
\hline 473. & $u_{473}$ & $A_{473}$ \\
\hline 474. & $u_{474}$ & $A_{474}$ \\
\hline
\end{tabular}


Langkah 2. Proses fuzzy logic relationship

a. Membuat fuzzy logic relationship orde 1, orde 2, orde 3, dan orde 4 berdasarkan formula berikut :

$$
F(t-n), \ldots, F(t-2), F(t-1) \rightarrow F(t)
$$

Tabel 7 : Fuzzy logic relationship orde 1, orde 2, orde 3, dan orde 4

\begin{tabular}{|c|c|c|c|c|c|}
\hline $\begin{array}{c}\text { No } \\
.\end{array}$ & Periode & FLR Orde 1 & $\begin{array}{c}\text { FLR Orde } \\
\mathbf{2}\end{array}$ & FLR Orde 3 & FLR Orde 4 \\
\hline 1. & Jan 2014 & - & - & - & - \\
\hline 2. & Feb 2014 & $A_{28} \rightarrow A_{38}$ & - & - & - \\
\hline 3. & Mar 2014 & $A_{38} \rightarrow A_{31}$ & $\begin{array}{c}A_{28}, A_{38} \rightarrow \\
A_{31}\end{array}$ & - & - \\
\hline 4. & Apr 2014 & $A_{31} \rightarrow A_{18}$ & $\begin{array}{c}A_{38}, A_{31} \rightarrow \\
A_{18}\end{array}$ & $\begin{array}{c}A_{28}, A_{38}, A_{31} \rightarrow \\
A_{18}\end{array}$ & - \\
\hline 5. & Mei 2014 & $A_{18} \rightarrow A_{18}$ & $\begin{array}{c}A_{31}, A_{18} \rightarrow \\
A_{18}\end{array}$ & $\begin{array}{c}A_{38}, A_{31}, A_{18} \rightarrow \\
A_{18}\end{array}$ & $\begin{array}{c}A_{28}, A_{38}, A_{31}, A_{18} \rightarrow \\
A_{18}\end{array}$ \\
\hline 6. & Jun 2014 & $A_{18} \rightarrow A_{29}$ & $\begin{array}{c}A_{18}, A_{18} \rightarrow \\
A_{29}\end{array}$ & $\begin{array}{c}A_{31}, A_{18}, A_{18} \rightarrow \\
A_{29}\end{array}$ & $\begin{array}{c}A_{38}, A_{31}, A_{18}, A_{18} \\
A_{29}\end{array}$ \\
\hline$\vdots$ & $\vdots$ & $\vdots$ & $\vdots$ & $\vdots$ & $\vdots$ \\
\hline 71. & Nov 2019 & $A_{219} \rightarrow A_{205}$ & $\begin{array}{c}A_{224}, A_{219} \rightarrow \\
A_{205}\end{array}$ & $\begin{array}{c}A_{227}, A_{224}, A_{219} \rightarrow \\
A_{205}\end{array}$ & $\begin{array}{c}A_{178}, A_{227}, A_{224}, A_{219} \\
A_{205}\end{array}$ \\
\hline 72. & Des 2019 & $A_{205} \rightarrow A_{207}$ & $\begin{array}{c}A_{219}, A_{205} \\
A_{207}\end{array}$ & $\begin{array}{c}A_{224}, A_{219}, A_{205} \\
A_{207}\end{array}$ & $\begin{array}{c}A_{227}, A_{224}, A_{219}, A_{205} \\
A_{207}\end{array}$ \\
\hline
\end{tabular}

b. Membuat fuzzy logic relationship groups yaitu dengan cara mengelompokkan fuzzy logic relationship yang memiliki sisi kiri yang sama

Tabel 8 : Fuzzy logic relationship groups orde 1, orde 2, orde 3, dan orde 4

\begin{tabular}{|c|c|c|c|c|}
\hline Grup & FLRG Orde 1 & FLRG Orde 2 & FLRG Orde 3 & FLRG Orde 4 \\
\hline 1 & $A_{1} \rightarrow A_{20}$ & $A_{1}, A_{20} \rightarrow A_{45}$ & $\begin{array}{l}A_{1}, A_{20}, A_{45} \\
\rightarrow A_{43}\end{array}$ & $\begin{array}{l}A_{1}, A_{20}, A_{45}, A_{43} \\
\rightarrow A_{35}\end{array}$ \\
\hline 2 & $A_{13} \rightarrow A_{17}$ & $A_{13}, A_{17} \rightarrow A_{1}$ & $\begin{array}{l}A_{13}, A_{17}, A_{1} \\
\rightarrow A_{20}\end{array}$ & $\begin{array}{l}A_{13}, A_{17}, A_{1}, A_{20} \\
\rightarrow A_{45}\end{array}$ \\
\hline 3 & $\begin{array}{l}A_{17} \\
\rightarrow A_{1}, A_{17}, A_{29}\end{array}$ & $A_{17}, A_{1} \rightarrow A_{20}$ & $\begin{array}{l}A_{17}, A_{1}, A_{20} \\
\rightarrow A_{45}\end{array}$ & $\begin{array}{l}A_{17}, A_{1}, A_{20}, A_{45} \\
\rightarrow A_{43}\end{array}$ \\
\hline$\vdots$ & $\vdots$ & $\vdots$ & $\vdots$ & $\vdots$ \\
\hline 68 & - & $\begin{array}{l}A_{219}, A_{205} \\
\rightarrow A_{207}\end{array}$ & $\begin{array}{l}A_{224}, A_{219}, A_{205} \\
\rightarrow A_{207}\end{array}$ & $\begin{array}{l}A_{227}, A_{224}, A_{219}, A_{207} \\
\rightarrow A_{207}\end{array}$ \\
\hline 69 & - & $\begin{array}{l}A_{224}, A_{219} \\
\rightarrow A_{205}\end{array}$ & $\begin{array}{l}A_{227}, A_{224}, A_{219} \\
\rightarrow A_{205}\end{array}$ & - \\
\hline 70 & - & $\begin{array}{l}A_{227}, A_{224} \\
\rightarrow A_{219}\end{array}$ & - & - \\
\hline
\end{tabular}


Langkah 3. Proses defuzzifikasi

Proses defuzzifikasi mengubah suatu besaran fuzzy menjadi besaran tegas. Keluaran dalam proses ini yaitu suatu peramalan dengan prinsip sebagai berikut :

1. $\operatorname{FLRG}\left(A_{i} \rightarrow A_{j}\right), F(t)=m_{j}$

2. $\operatorname{FLRG}\left(A_{i} \rightarrow A_{1}\left(x_{1}\right), \ldots, A_{p}\left(x_{p}\right)\right), F(t)=\frac{x_{1} m_{1}+\cdots+x_{p} m_{p}}{x_{1}+\cdots+x_{p}}$

3. $\operatorname{FLRG}\left(A_{i} \rightarrow \emptyset\right), F(t)=m_{i}$

dimana $m_{j}, m_{p}, m_{i}$ adalah nilai tengah dari masing-masing interval $u_{j}, u_{p}, u_{i}$ dan $x_{p}$ adalah jumlah dari fuzzy logic relationship $A_{i} \rightarrow A_{p}$.

Tabel 9 : Hasil perhitungan peramalan pada data training

\begin{tabular}{|c|c|c|c|c|c|c|}
\hline No. & Periode & $\begin{array}{c}\text { Data } \\
\text { Aktual }\end{array}$ & $\begin{array}{c}\text { Peramalan } \\
\text { Orde 1 }\end{array}$ & $\begin{array}{c}\text { Peramalan } \\
\text { Orde 2 }\end{array}$ & $\begin{array}{c}\text { Peramalan } \\
\text { Orde 3 }\end{array}$ & $\begin{array}{c}\text { Peramalan } \\
\text { Orde 4 }\end{array}$ \\
\hline 1. & Jan 2014 & 488222 & - & - & - & - \\
\hline 2. & Feb 2014 & 498420 & 485725 & - & - & - \\
\hline 3. & Mar 2014 & 491356 & 491225 & 491225 & - & - \\
\hline 4. & Apr 2014 & 477877 & 478225 & 478225 & 478225 & - \\
\hline 5. & Mei 2014 & 477997 & 483725 & 478225 & 478225 & 478225 \\
\hline 6. & Jun 2014 & 489516 & 483725 & 489225 & 489225 & 489225 \\
\hline$\vdots$ & $\vdots$ & $\vdots$ & $\vdots$ & $\vdots$ & $\vdots$ & $\vdots$ \\
\hline 71. & Nov 2019 & 665454 & 665225 & 665225 & 665225 & 665225 \\
\hline 72. & Des 2019 & 667423 & 667225 & 667225 & 667225 & 667225 \\
\hline
\end{tabular}

\subsubsection{Perhitungan Tingkat Akurasi Metode Fuzzy Logic Relationship}

Nilai MAPE untuk metode fuzzy logic relationship dilakukan dengan perhitungan sebagai berikut :

$$
M A P E=\frac{1}{72} \sum_{t=1}^{72}\left|\frac{X(t)-F(t)}{X(t)}\right| \times 100 \%
$$

dimana $X(t)$ adalah data aktual dari masing-masing periode dan $F(t)$ adalah data peramalan dari masing-masing periode.

Tabel 10 : Perbandingan tingkat akurasi metode fuzzy logic relationship

\begin{tabular}{|c|c|c|}
\hline No. & Metode & MAPE \\
\hline 1. & Fuzzy logic relationship orde 1 & $0,6693 \%$ \\
\hline 2. & Fuzzy logic relationship orde 2 & $0,0509 \%$ \\
\hline 3. & Fuzzy logic relationship orde 3 & $0,0506 \%$ \\
\hline 4. & Fuzzy logic relationship orde 4 & $0,0496 \%$ \\
\hline
\end{tabular}




\subsubsection{Perhitungan Peramalan Harga pada Data Testing}

Perhitungan peramalan harga emas pada data testing dalam membentuk fuzzy logic relationship, hasil fuzzifikasi data 4 periode sebelumnya direlasikan dengan $\varnothing$ karena dalam perhitungan ini seolah-olah penulis tidak mengetahui harga emas pada waktu $t$ seperti yang disajikan dalam Tabel 11 .

Tabel 11 : Fuzzy logic relationship dan Fuzzy logic relationship groups data testing

\begin{tabular}{|c|c|c|c|}
\hline No. & Periode & FLR & FLRG \\
\hline 1. & Januari 2020 & $A_{224}, A_{219}, A_{205}, A_{207} \rightarrow \emptyset$ & $A_{224}, A_{219}, A_{205}, A_{207} \rightarrow \emptyset$ \\
\hline 2. & Februari 2020 & $A_{219}, A_{205}, A_{207}, A_{229} \rightarrow \emptyset$ & $A_{219}, A_{205}, A_{207}, A_{229} \rightarrow \emptyset$ \\
\hline 3. & Maret 2020 & $A_{205}, A_{207}, A_{229}, A_{247} \rightarrow \emptyset$ & $A_{205}, A_{207}, A_{229}, A_{247} \rightarrow \emptyset$ \\
\hline 4. & April 2020 & $A_{207}, A_{229}, A_{247}, A_{319} \rightarrow \emptyset$ & $A_{207}, A_{229}, A_{247}, A_{319} \rightarrow \emptyset$ \\
\hline 5. & Mei 2020 & $A_{229}, A_{247}, A_{319}, A_{399} \rightarrow \emptyset$ & $A_{229}, A_{247}, A_{319}, A_{399} \rightarrow \emptyset$ \\
\hline 6. & Juni 2020 & $A_{247}, A_{319}, A_{399}, A_{364} \rightarrow \emptyset$ & $A_{247}, A_{319}, A_{399}, A_{364} \rightarrow \emptyset$ \\
\hline 7. & Juli 2020 & $A_{319}, A_{399}, A_{364}, A_{333} \rightarrow \emptyset$ & $A_{319}, A_{399}, A_{364}, A_{333} \rightarrow \emptyset$ \\
\hline 8. & Agustus 2020 & $A_{399}, A_{364}, A_{333}, A_{403} \rightarrow \emptyset$ & $A_{399}, A_{364}, A_{333}, A_{403} \rightarrow \emptyset$ \\
\hline 9. & September & $A_{364}, A_{333}, A_{403}, A_{474} \rightarrow \emptyset$ & $A_{364}, A_{333}, A_{403}, A_{474} \rightarrow \emptyset$ \\
\hline
\end{tabular}

Fuzzy logic relationship groups yang telah terbentuk kemudian dilakukan proses defuzzifikasi dengan prinsip sebagai berikut :

1. $\operatorname{FLRG}\left(A_{i}, A_{h}, A_{f}, A_{g} \rightarrow A_{j}\right), F(t)=m_{j}$

2. $\operatorname{FLRG}\left(A_{i}, A_{h}, A_{f}, A_{g} \rightarrow A_{1}\left(x_{1}\right), \ldots, A_{p}\left(x_{p}\right)\right), F(t)=\frac{x_{1} m_{1}+\cdots+x_{p} m_{p}}{x_{1}+\cdots+x_{p}}$

3. $\operatorname{FLRG}\left(A_{i}, A_{h}, A_{f}, A_{g} \rightarrow \emptyset\right), F(t)=\frac{m_{i}+m_{h}+m_{f}+m_{g}}{4}$ dimana $m_{j}, m_{p}, m_{i}, m_{h}, m_{g}, m_{f}$ adalah nilai tengah dari masing-masing interval $u_{j}, u_{p}, u_{i}, u_{h}, u_{g}, u_{f}$ dan $x_{p}$ adalah jumlah dari fuzzy logic relationship $A_{i}, A_{h}, A_{f}, A_{g} \rightarrow A_{p}$.

Tabel 12: Hasil perhitungan peramalan pada data testing

\begin{tabular}{|c|c|c|c|}
\hline No. & Bulan & Data aktual & Peramalan \\
\hline 1. & Januari 2020 & 688784 & 673975 \\
\hline 2. & Februari 2020 & 706989 & 675225 \\
\hline 3. & Maret 2020 & 779341 & 682225 \\
\hline 4. & April 2020 & 859511 & 710725 \\
\hline 5. & Mei 2020 & 824617 & 758725 \\
\hline 6. & Juni 2020 & 792736 & 792475 \\
\hline 7. & Juli 2020 & 862791 & 813975 \\
\hline 8. & Agustus 2020 & 934132 & 834975 \\
\hline 9. & September 2020 & 917295 & 853725 \\
\hline
\end{tabular}




\subsubsection{Perhitungan Peramalan Harga Emas}

Perhitungan peramalan harga emas bulan Oktober 2020 - Desember 2021 menggunakan metode fuzzy logic relationship orde 4 yang memiliki nilai MAPE sebesar 0,0496 dimulai dengan pembentukan fuzzy logic relationship.

Tabel 13 : Fuzzy logic relationship dan Fuzzy logic relationship groups

\begin{tabular}{|c|c|c|c|}
\hline No. & Periode & FLR & FLRG \\
\hline 1. & Oktober 2020 & $A_{333}, A_{403}, A_{474}, A_{457} \rightarrow \emptyset$ & $A_{333}, A_{403}, A_{474}, A_{457} \rightarrow \emptyset$ \\
\hline 2. & November 2020 & $A_{403}, A_{474}, A_{457}, A_{417} \rightarrow \emptyset$ & $A_{403}, A_{474}, A_{457}, A_{417} \rightarrow \emptyset$ \\
\hline 3. & Desember 2020 & $A_{474}, A_{457}, A_{417}, A_{438} \rightarrow \emptyset$ & $A_{474}, A_{457}, A_{417}, A_{438} \rightarrow \emptyset$ \\
\hline 4. & Januari 2021 & $A_{457}, A_{417}, A_{438}, A_{466} \rightarrow \emptyset$ & $A_{457}, A_{417}, A_{438}, A_{466} \rightarrow \emptyset$ \\
\hline 5. & Februari 2021 & $A_{417}, A_{438}, A_{466}, A_{444} \rightarrow \emptyset$ & $A_{417}, A_{438}, A_{466}, A_{444} \rightarrow \emptyset$ \\
\hline 6. & Maret 2021 & $A_{438}, A_{466}, A_{444}, A_{441} \rightarrow \emptyset$ & $A_{438}, A_{466}, A_{444}, A_{441} \rightarrow \emptyset$ \\
\hline 7. & April 2021 & $A_{466}, A_{444}, A_{441}, A_{447} \rightarrow \emptyset$ & $A_{466}, A_{444}, A_{441}, A_{447} \rightarrow \emptyset$ \\
\hline 8. & Mei 2021 & $A_{444}, A_{441}, A_{447}, A_{449} \rightarrow \emptyset$ & $A_{444}, A_{441}, A_{447}, A_{449} \rightarrow \emptyset$ \\
\hline 9. & Juni 2021 & $A_{441}, A_{447}, A_{449}, A_{445} \rightarrow \emptyset$ & $A_{441}, A_{447}, A_{449}, A_{445} \rightarrow \emptyset$ \\
\hline 10. & Juli 2021 & $A_{447}, A_{449}, A_{445}, A_{446} \rightarrow \emptyset$ & $A_{447}, A_{449}, A_{445}, A_{446} \rightarrow \emptyset$ \\
\hline 11. & Agustus 2021 & $A_{449}, A_{445}, A_{446}, A_{447} \rightarrow \emptyset$ & $A_{449}, A_{445}, A_{446}, A_{447} \rightarrow \emptyset$ \\
\hline 12. & September 2021 & $A_{445}, A_{446}, A_{447}, A_{447} \rightarrow \emptyset$ & $A_{445}, A_{446}, A_{447}, A_{447} \rightarrow \emptyset$ \\
\hline 13. & Oktober 2021 & $A_{446}, A_{447}, A_{447}, A_{446} \rightarrow \emptyset$ & $A_{446}, A_{447}, A_{447}, A_{446} \rightarrow \emptyset$ \\
\hline 14. & November 2021 & $A_{447}, A_{447}, A_{446}, A_{447} \rightarrow \emptyset$ & $A_{447}, A_{447}, A_{446}, A_{447} \rightarrow \emptyset$ \\
\hline 15. & Desember 2021 & $A_{447}, A_{447}, A_{447}, A_{447} \rightarrow \emptyset$ & $A_{447}, A_{447}, A_{447}, A_{447} \rightarrow \emptyset$ \\
\hline & & & \\
\hline
\end{tabular}

Fuzzy logic relationship groups yang telah terbentuk kemudian dilakukan proses defuzzifikasi dengan prinsip sebagai berikut :

1. $\operatorname{FLRG}\left(A_{i}, A_{h}, A_{f}, A_{g} \rightarrow A_{j}\right), F(t)=m_{j}$

2. $\operatorname{FLRG}\left(A_{i}, A_{h}, A_{f}, A_{g} \rightarrow A_{1}\left(x_{1}\right), \ldots, A_{p}\left(x_{p}\right)\right), F(t)=\frac{x_{1} m_{1}+\cdots+x_{p} m_{p}}{x_{1}+\cdots+x_{p}}$

3. $\operatorname{FLRG}\left(A_{i}, A_{h}, A_{f}, A_{g} \rightarrow \emptyset\right), F(t)=\frac{m_{i}+m_{h}+m_{f}+m_{g}}{4}$

dimana $m_{j}, m_{p}, m_{i}, m_{h}, m_{g}, m_{f}$ adalah nilai tengah dari masing-masing interval $u_{j}, u_{p}, u_{i}, u_{h}, u_{g}, u_{f}$ dan $x_{p}$ adalah jumlah dari fuzzy logic relationship $A_{i}, A_{h}, A_{f}, A_{g} \rightarrow A_{p}$.

Tabel 14 : Hasil perhitungan peramalan

\begin{tabular}{|c|c|c|}
\hline No. & Periode & Peramalan \\
\hline 1. & Oktober 2020 & 876975 \\
\hline 2. & November 2020 & 897975 \\
\hline 3. & Desember 2020 & 906725 \\
\hline 4. & Januari 2021 & 899975 \\
\hline 5. & Februari 2021 & 895725 \\
\hline 6. & Maret 2021 & 900475 \\
\hline
\end{tabular}




\begin{tabular}{|c|c|c|}
\hline 7. & April 2021 & 900975 \\
\hline 8. & Mei 2021 & 899475 \\
\hline 9. & Juni 2021 & 899225 \\
\hline 10. & Juli 2021 & 899975 \\
\hline 11. & Agustus 2021 & 899975 \\
\hline 12. & September 2021 & 899725 \\
\hline 13. & Oktober 2021 & 899975 \\
\hline 14. & November 2021 & 900225 \\
\hline 15. & Desember 2021 & 900225 \\
\hline
\end{tabular}

\subsection{Pembahasan}

Dalam penelitian ini, perhitungan metode average based and fuzzy logic relationship dimulai dari orde 1 , orde 2 , orde 3 dan seterusnya. Namun, dikarenakan nilai MAPE pada masing-masing orde terus menurun, maka peramalan dilakukan sampai dengan orde 4 yang sudah memiliki tingkat akurasi sangat baik yaitu 0,0496\% dan juga dapat meramalkan 15 periode sehingga Fuzzy Logic Relationship orde 4 digunakan untuk menghitung data testing dan data peramalan. Hasil peramalan menggunakan metode average based and fuzzy logic relationship orde 4 menunjukkan bahwa pada bulan Oktober 2020 harga emas mengalami penurunan dibandingkan dengan harga emas sebelumnya yaitu $R p$ 876.975/gram. Sehingga, bulan tersebut merupakan waktu yang tepat bagi investor membeli emas agar memperoleh keuntungan. Berdasarkan tabel 16, investor dapat menjual emas sekitar bulan November 2020 - Desember 2021 karena harga emas berada pada kisaran Rp 897.975/gram Rp 906.725/gram.

Tabel 15 : Hasil perhitungan peramalan harga emas 24 karat

\begin{tabular}{|c|c|l|}
\hline No. & Periode & Peramalan \\
\hline 1. & Oktober 2020 & $R p 876.975 / \mathrm{gram}$ \\
\hline 2. & November 2020 & $R p 897.975 / \mathrm{gram}$ \\
\hline 3. & Desember 2020 & $R p 906.725 / \mathrm{gram}$ \\
\hline 4. & Januari 2021 & $R p 899.975 / \mathrm{gram}$ \\
\hline 5. & Februari 2021 & $R p 895.725 / \mathrm{gram}$ \\
\hline 6. & Maret 2021 & $R p 900.475 / \mathrm{gram}$ \\
\hline 7. & April 2021 & $R p 900.975 / \mathrm{gram}$ \\
\hline 8. & Mei 2021 & $R p 899.475 / \mathrm{gram}$ \\
\hline 9. & Juni 2021 & $R p 899.225 / \mathrm{gram}$ \\
\hline 10. & Juli 2021 & $R p 899.975 / \mathrm{gram}$ \\
\hline 11. & Agustus 2021 & $R p 899.975 / \mathrm{gram}$ \\
\hline
\end{tabular}




\begin{tabular}{|c|c|c|}
\hline 12. & September 2021 & $R p 899.725 /$ gram \\
\hline 13. & Oktober 2021 & $R p 899.975 /$ gram \\
\hline 14. & November 2021 & $R p 900.225 / \mathrm{gram}$ \\
\hline 15. & Desember 2021 & $R p 900.225 / \mathrm{gram}$ \\
\hline
\end{tabular}

\section{KESIMPULAN}

Berdasarkan hasil perhitungan yang telah dilakukan dalam meramalkan harga emas 24 karat menggunakan metode average based and fuzzy logic relationship, maka dapat disimpulkan bahwa :

1. Hasil perhitungan peramalan harga emas 24 karat menggunakan metode average based and fuzzy logic relationship orde 4 pada bulan Oktober 2020 - Januari 2021 dapat disajikan dalam Tabel 5.

2. Nilai tingkat akurasi metode average based and fuzzy logic relationship orde 4 menggunakan MAPE diperoleh sebesar 0,0496\% yang artinya metode ini sangat baik digunakan untuk meramalkan harga emas.

\section{DAFTAR PUSTAKA}

[1]. Aditya, F., Devianto, D., dan Maiyastri. (2019). Peramalan Harga Emas Indonesia Menggunakan Metode Fuzzy Time Series Klasik. Matematika UNAND, VIII, 45-52.

[2]. Fajri, A. (2017). Analisis Prinsip Ekonomi Islam Terhadap Operasional Produk Investasi Emas Pada Penggadaian Syariah. Skripsi. Fakultas Ekonomi Dan Bisnis Islam, Universitas Islam Negeri Alauddin Makassar. http://repositori.uinalauddin.ac.id/view/creators/Fajri=3AA=2E_Nur_Wahana=3A=3A.ht $\mathrm{ml}$.

[3]. Fauziah, N., Wahyuningsih, S., dan Nasution, Y. (2016). Peramalan Menggunakan Fuzzy Time Series Chen (Studi Kasus : Curah Hujan Kota Samarinda). Statistika, 4(2).

[4]. Febriana, E. (2018). Fuzzy Time Series Chen Orde Tinggi Untuk Meramalkan Jumlah Penumpang dan Kendaraan Kapal. Skripsi. Fakultas Matematika dan IImu Pengetahuan Alam, Universitas Islam Indonesia. https://dspace.uii.ac.id.

[5]. Handayani, L., dan Anggriani, D. (2015). Perbandingan Model Chen Dan Model Lee Pada Metode Fuzzy Time Series Untuk Prediksi Harga Emas. Jurnal Pseudocode, 2(1), 23555920.

[6]. Ikhsanto, H. (2016). Perbandingan Tingkat Akurasi Metode Automatic Clutering, Average Based, dan Markov Chain Fuzzy Time Series pada Nilai Tukar (Kurs) Rupiah. Skripsi. Fakultas Matematika dan IImu Pengetahuan Alam, Universitas Negeri Semarang. https://lib.unnes.ac.id 
[7]. Iman, N. (2008). Panduan Singkat dan Praktis Memulai Investasi. Jakarta: PT. Elex Media Komputindo.

[8]. Kasmir dan Jakfar. (2013). Studi Kelayakan Bisnis. Jakarta : Kencana Prenada Media Group.

[9]. Kurniawan, I. (2019). Analisis Keuntungan Investasi Emas dengan IHSG. Jurnal Manajemen Bisnis dan Kewirausahaan, 3(2), 16-23.

[10]. Purnama, D. (2014). Emas : Antara Mata Uang dan Komoditas. Jurnal Ekonomi dan Hukum Islam, 4(1), 2088-6365.

[11]. Rahmawati, D. (2013). Peramalan Permintaan Jamu Dengan Mengimplementasikan Metode Average-Based Fuzzy Time Series. Skripsi. Fakultas Sains Dan Tekhnologi, Universitas Islam Negeri Maulana Malik Ibrahim, Malang. http://etheses.uin-malang.ac.id

[12]. Rukhansah, N., Muslim, M., dan Arifudin, R. (2016). Peramalan Harga Emas Menggunakan Fuzzy Time Series Markov Chain Model. Komputaki, 1(1).

[13]. Sitohang, S., dan Siringo, A. M. (2018). Analisis Peramalan Harga Emas Dengan Metode Automatic Clustering And Fuzzy Logic Relationship. Information System Development [ISD], 3, 104-115.

[14]. Sujarwata. (2014). Buku Ajar System Fuzzy dan Aplikasinya. Semarang : Universitas Negeri Semarang.

[15]. Surya, M. dan Fauziyah, A. (2016). Peluang Investasi Emas Jangka Panjang Melalui Produk Pembiayaan BSM Cicil Emas. Jurnal Pemikiran Islam, XVI (1), 57-73.

[16]. Xihao, S. And Yimin, L. (2008). Average-Based Fuzy Time Series Models For Forecasting Shanghai Compound Index. World Journal Of Modelling And Simulation, 4(2), 104-111.

[17]. Yani, A. (2017). Minat Masyarakat Terhadap Investasi Logam Mulia di Pegadaian Syariah Upc Semangka Kota Bengkulu. Skripsi. Fakultas Ekonomi dan Bisnis Islam, Institut Agama Islam Negeri Bengkulu. https://repository.iainbengkulu.ac.id 